\title{
Detection of Plasmodium in faeces of the New World primate Alouatta clamitans
}

\author{
Gabriela Maíra Pereira de Assis ${ }^{1}$, Denise Anete Madureira de Alvarenga', \\ Daniela Camargos Costa', Júlio César de Souza Junior,3, Zelinda Maria Braga Hirano ${ }^{2,3}$, \\ Flora Satiko Kano', Taís Nóbrega de Sousa', Cristiana Ferreira Alves de Brito ${ }^{1 /+}$
}

\footnotetext{
${ }^{1}$ Fundação Oswaldo Cruz, Centro de Pesquisas René Rachou, Laboratório de Malária, Belo Horizonte, MG, Brasil ${ }^{2}$ Universidade Regional de Blumenau, Blumenau, SC, Brasil ${ }^{3}$ Centro de Pesquisas Biológicas de Indaial, Indaial, SC, Brasil
}

\begin{abstract}
Plasmodium falciparum and Plasmodium vivax have evolved with host switches between non-human primates (NHPs) and humans. Studies on the infection dynamics of Plasmodium species in NHPs will improve our understanding of the evolution of these parasites; however, such studies are hampered by the difficulty of handling animals in the field. The aim of this study was to detect genomic DNA of Plasmodium species from the faeces of New World monkeys. Faecal samples from 23 Alouatta clamitans from the Centre for Biological Research of Indaial (Santa Catarina, Brazil) were collected. Extracted DNA from faecal samples was used for molecular diagnosis of malaria by nested polymerase chain reaction. One natural infection with Plasmodium simium was identified by amplification of DNA extracted from the faeces of A. clamitans. Extracted DNA from a captive NHP was also used for parasite genotyping. The detection limit of the technique was evaluated in vitro using an artificial mixture of cultured $\mathrm{P}$. falciparum in NHP faeces and determined to be 6.5 parasites/ $\mu \mathrm{L}$. Faecal samples of New World primates can be used to detect malaria infections in field surveys and also to monitor the genetic variability of parasites and dynamics of infection.
\end{abstract}

Key words: New World primates - Alouatta clamitans - simian malaria -

Plasmodium simium - Plasmodium vivax - non-invasive sampling

Malaria is a mosquito-borne disease caused by parasites of the genus Plasmodium that infect mammals, reptiles and birds. Plasmodium species that infect non-human primates (NHPs) are of great interest because they may be transmitted, naturally or accidentally, to humans (Deane et al. 1966, Arruda et al. 1989, Singh et al. 2004). Human infections with Plasmodium knowlesi, a parasite that naturally infects Old World monkeys (mainly $\mathrm{Ma}$ caca nemestrina and Macaca fascicularis), have reinforced the thought that the proximity of humans to forests allows diseases that circulate naturally among wild animals to also occur in humans (White 2008). Malaria caused by $P$. knowlesi in humans is highly virulent and often has a fatal outcome (Galinski \& Barnwell 2009). Infections with this pathogen have been recently reported in many countries of Southeast Asia (Yusof et al. 2014).

In addition to $P$. knowlesi, there are several other species of Plasmodium that infect NHPs: Plasmodium cynomolgi (Mayer, 1907), Plasmodium inui (Von Halberstaedter \& Prowazek, 1907) and Plasmodium schwetzi (Warrell, 2002), among others. Two parasite species are responsible for simian malaria in the forests of Central and South America: Plasmodium brasilianum (Gonder

doi: 10.1590/0074-02760160222

Financial support: CNPq, FAPEMIG.

$\mathrm{CFAB}$ is a recipient of the research fellowship from CNPq.

+ Corresponding author: cristiana@cpqrr.fiocruz.br

Received 24 May 2016

Accepted 29 June 2016
\& Berenberg-Gossler, 1908) and Plasmodium simium (Fonseca, 1939). Importantly, both $P$. brasilianum and $P$. simium can infect humans (Deane et al. 1966, Arruda et al. 1989, Cerutti-Junior et al. 2007). These parasites are morphologically, genetically and immunologically similar to the human parasites Plasmodium malariae and Plasmodium vivax, respectively (Deane 1992, Leclerc et al. 2004, Cerutti-Junior et al. 2007). Such similarities gave rise to the hypothesis that monkeys may act as a reservoir for human malaria in specific areas (Coatney 1971, Fandeur et al. 2000, Duarte et al. 2008). P. brasilianum is widely distributed in Central and South America. It has been found in Brazil, Colombia, Venezuela, Panama and Peru. This species naturally infects various New World monkey species, including those from the families: Aotidae, Atelidae, Callitrichidae, Cebidae and Pitheciidae (Deane 1992, Lourenço-de-Oliveira \& Deane 1995, Araújo et al. 2013). In Brazil, except for the arid portions of the northeast and savannah in the southeast, the geographic range of $P$. brasilianum includes all regions and overlaps that of $P$. simium, which is restricted to the Atlantic Forest in the south and southeast (Deane 1992). In contrast to P. brasilianum, P. simium has been detected only in Alouatta (howler monkeys), Brachyteles (woolly spider monkeys) and, more recently, Cebus and Sapajus (capuchin monkeys) (Deane 1992, Duarte et al. 2008, Alvarenga et al. 2015).

Therefore, molecular studies of simian Plasmodium species are indispensable to understanding the true prevalence, transmission dynamics, and diversity of this parasite, as well as to elucidate the evolutionary history of Plasmodium species in the New World. However, the 
use of blood samples for both optical microscopy and for diagnostics based on molecular techniques is hampered by the need to capture and handle wild animals in the field, which is not feasible in many situations. Therefore, DNA extracted from samples that are collected using a simple, less invasive and inexpensive method can facilitate a better understanding of simian malaria, as well as provide information for phylogenetic analyses of these parasites. Recent studies have shown that saliva, urine and faeces from malaria patients contain trace amounts of Plasmodium DNA that can be amplified by polymerase chain reaction (PCR) and, therefore, can be used as alternative specimens for epidemiological surveys (Nwakanma et al. 2009, Jirků et al. 2012). For phylogenetic studies of Plasmodium, DNA sequences have been obtained from faecal samples of Old World monkeys. A recent study elucidated the origin of $P$. falciparum and its reservoir using this approach (Liu et al. 2010). Another study conducted by Liu and colleagues (Liu et al. 2014) indicated that all strains of $P$. vivax are derived from a single ancestor that escaped out of Africa. This study was based on DNA extractions from chimpanzee and gorilla faeces from Africa. In 2015, Siregar and colleagues (Siregar et al. 2015) optimised protocols for the non-invasive sampling and isolation of malaria parasites from naturally infected Old World monkeys. However, despite the successful molecular diagnosis of malaria from faeces of Old World monkeys, this methodology has not been standardised for New World monkeys.

\section{MATERIALS AND METHODS}

Monkey faecal sample collection - For this study, faeces were collected from captive NHPs from the Centre for Biological Research of Indaial (CEPESBI), Santa Catarina, Brazil. CEPESBI (IBAMA register number $1 / 42 / 98 / 000708-90)$ is a unit for wild monkey protection, located in the Valley of Itajaí (26 53 '52" S/49¹3'54" W) in the Atlantic Forest. Faecal samples from Alouatta guariba clamitans $(\mathrm{n}=23)$ were stored in RNAlater (Qiagen) at a ratio of 1:2 and transferred to $-20^{\circ} \mathrm{C}$ within $24 \mathrm{~h}$, where they were held until DNA was extracted.

DNA extraction from faecal samples - First, the faeces in RNAlater were placed in gauze to remove any leaves and seeds. DNA was extracted from faecal samples using a modified protocol for the QIAamp DNA Mini Stool Kit (Qiagen). To lyse cells, $500 \mu \mathrm{L}$ of a faecal sample in RNAlater was homogenised in $5 \mathrm{~mL}$ of ASL buffer and vortexed. This suspension was heated to $70^{\circ} \mathrm{C}$ for $5 \mathrm{~min}$, vortexed for 15 more sec, and centrifuged for $1 \mathrm{~min}$ at $20,000 \times g$ to obtain aggregate faecal particles. The supernatant $(1.2 \mathrm{~mL})$ was transferred to a new $2-\mathrm{mL}$ microcentrifuge tube, and the pellet was discarded. Then, half of an InhibitEX tablet was added to each sample, and the sample was vortexed immediately for 1 min or until the tablet was completely dissolved. The resulting suspension was centrifuged at $20,000 \times g$ for 3 $\min$. For the rest of the procedures, the manufacturer's instructions were followed. To elute the DNA, $100 \mu \mathrm{L}$ of Buffer $\mathrm{AE}$ was added, incubated for $5 \mathrm{~min}$ at room temperature $\left(20-24^{\circ} \mathrm{C}\right)$, and centrifuged at $20,000 \times g$ for
1 min. Finally, the DNA was stored at $-20^{\circ} \mathrm{C}$. Filter pipette tips were used in all stages of sample processing to prevent cross-contamination.

Artificial mixture with cultured P. falciparum - One hundred microliters of cultured P. falciparum strain 3D7 (parasitaemia of $6.5 \times 10^{5}$ parasites $/ \mu \mathrm{L}$ ) was added to $400 \mu \mathrm{L}$ of uninfected brown howler monkey stool (in RNAlater, 1:2). The same procedure was performed with cultured $P$. falciparum strain W2 (parasitaemia of 5.0 $\times 10^{5}$ parasites $/ \mu \mathrm{L}$ ). DNA was extracted from these artificial mixtures using a QIAamp DNA Stool Mini Kit (Qiagen) as described above. DNA obtained from $P$. falciparum 3D7 mixed with faeces was 10-fold diluted from 1:100 to $1: 1,000,000$. These dilutions were tested by nested PCR to diagnose malaria (Snounou et al. 1993).

PCR of the mammalian cytochrome B gene - To assess the quality of DNA from samples, the mammalian cytochrome B gene was amplified by PCR. The protocol described by Kocher et al. (1989) was used with modifications. A fragment of $350 \mathrm{bp}$ was amplified from a reaction volume of $20 \mu \mathrm{L}$ containing 50-100 ng of DNA, $0.625 \mathrm{mM}$ each primer (Table I), $0.125 \mathrm{mM}$ each dNTP, $1.875 \mathrm{mM} \mathrm{MgCl}, 1 \mathrm{U}$ Taq DNA polymerase (Invitrogen, California, USA), and the enzyme buffer provided by the manufacturer. The reactions were carried out in a Mastercycler personal thermocycler (Eppendorf). The cycling conditions included one step of $95^{\circ} \mathrm{C}$ for $5 \mathrm{~min}$, followed by 35 cycles at $95^{\circ} \mathrm{C}$ for $30 \mathrm{sec}, 58^{\circ} \mathrm{C}$ for $30 \mathrm{sec}$, and $72^{\circ} \mathrm{C}$ for $1 \mathrm{~min}$, and ended in an extension step at $72^{\circ} \mathrm{C}$ for $5 \mathrm{~min}$ and $4^{\circ} \mathrm{C}$ until the products were collected.

Molecular diagnosis of Plasmodium infection - The samples were subjected to nested PCR, as described by Snounou et al. (1993), using primers to detect human Plasmodium species ( $P$. falciparum, $P$. vivax and $P$. malariae) by targeting the small subunit (SSU) $18 \mathrm{~S}$ of the ribosomal RNA (18S rRNA) gene (Table I). Briefly, all PCR reactions were performed in $20-\mu \mathrm{L}$ volumes containing 250 $\mu \mathrm{M}$ each primer, $10 \mu \mathrm{L}$ of Master Mix (Promega) $(0.3$ units of Taq polymerase, $200 \mu \mathrm{M}$ each DNTP, and 1.5 $\mathrm{mM} \mathrm{MgCl})$, and $0.8 \mu \mathrm{L}(\sim 100-200 \mathrm{ng})$ of DNA. Bovine serum albumin (BSA) was added to the PCR mixture at a final concentration of $0.1 \mu \mathrm{g} / \mu \mathrm{L}$. PCR assays were performed using an automatic thermocycler (PTC-100TM v. 7.0) (MJ Research, Inc., USA) with the following cycling parameters: an initial denaturation step at $95^{\circ} \mathrm{C}$ for $5 \mathrm{~min}$, followed by 24 cycles of $58^{\circ} \mathrm{C}$ for $2 \mathrm{~min}, 72^{\circ} \mathrm{C}$ for $2 \mathrm{~min}$, and $94^{\circ} \mathrm{C}$ for $1 \mathrm{~min}$, and one final step at $58^{\circ} \mathrm{C}$ for $2 \mathrm{~min}$, an extension at $72^{\circ} \mathrm{C}$ for $5 \mathrm{~min}$, and then $4^{\circ} \mathrm{C}$ until the products were collected. The cycling parameters for the second round of PCR were the same as the first reaction, except for the use of 29 cycles for amplification.

To prevent cross-contamination, the DNA extracts and PCR preparations were performed in "parasite DNA-free rooms" that were distinct from each other. Furthermore, each of these separate areas had different sets of pipettes, and all procedures were performed using pipette tips with aerosol barriers. DNA extraction was performed twice on different days. Every PCR reaction had a negative control, in which DNA has replaced 


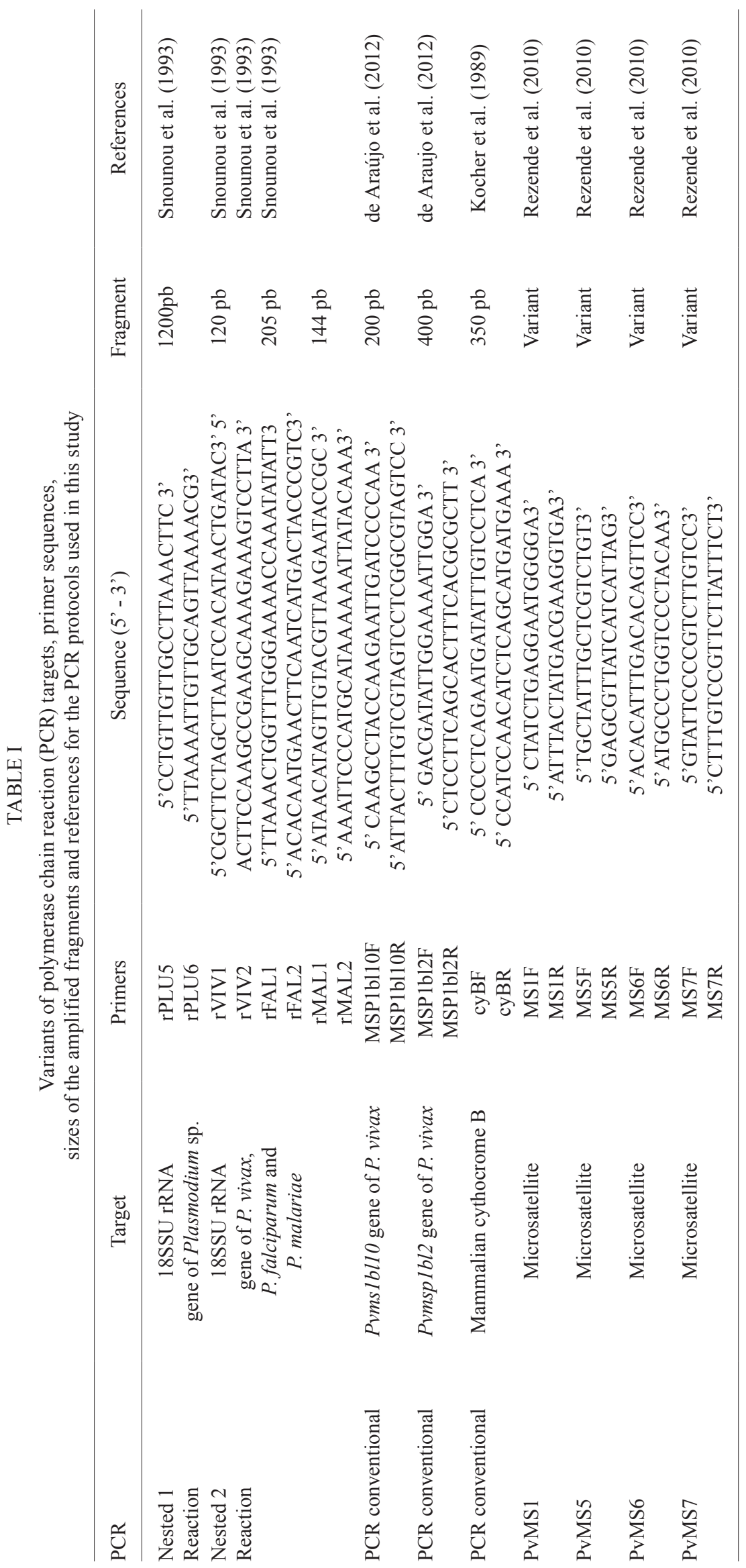


by water, as well as positive controls for each pair of primers. The sources of genomic DNA used as positive controls in the nested PCR were $P$. falciparum strain 3D7 maintained in the Laboratory of Malaria (René Rachou Research Centre - CPqRR, FIOCRUZ, Belo Horizonte, Minas Gerais, Brazil), a patient with a high $P$. vivax parasitaemia confirmed by Giemsa-stained blood smears, and a plasmid containing DNA from $P$. malariae (MRA-179 P. malariae small subunit rRNA Nest 1 PCR Plasmid Clone 34-MR4). The amplified fragments were resolved by electrophoresis on $2 \%$ agarose gel dissolved in TAE buffer (40 mM Tris-acetate, $1 \mathrm{mM}$ EDTA) in a horizontal system (Bio-Rad) at $100 \mathrm{~V}$ for approximately $30 \mathrm{~min}$. Gels were stained with $5 \mu \mathrm{g} / \mathrm{mL}$ ethidium bromide (Invitrogen) and examined under a UV transilluminator (BioDoc-It system), and images were captured using a digital system. Electrophoresis was performed in a room specifically for use with amplified DNA, with dedicated sets of pipettes and pipette tips with barriers.

Genotyping of molecular markers - Six molecular markers were selected for this study: blocks 2 and 10 of the merozoite surface protein-1 gene of $P$. vivax (PvmsplB2 and $P$ vmsp1B10) and four $P$. vivax microsatellites (MSs; PvMS1, PvMS5, PvMS6 and PvMS7). These fragments were amplified using specific primers and previously described conditions with minor modifications (Rezende et al. 2010, de Araújo et al. 2012). All forward primers for genotyping were conjugated to the fluorescent dye 6-FAM. Nested PCR was used to amplify both Pvmspl blocks (BL2 and BL10). The first reaction was conducted in a volume of $10 \mu \mathrm{L}$ using 100-200 ng DNA, $0.5 \mu \mathrm{M}$ each primer (Integrated DNA Technologies, San Diego, CA, USA) (Table I), $0.125 \mathrm{mM}$ dNTP mix, $0.75 \mathrm{mM} \mathrm{MgCl}_{2}$, 1 U Taq DNA polymerase (Invitrogen, California, USA), and appropriate enzyme buffer. The amplifications were performed on a Veriti thermocycler (Applied Biosystems, Carlsbad, CA, USA), using the following cycling conditions: $94^{\circ} \mathrm{C}$ for $4 \mathrm{~min} ; 30$ cycles of $94^{\circ} \mathrm{C}$ for $1 \mathrm{~min}$, then $55^{\circ} \mathrm{C}$ for $1 \mathrm{~min}$ for $P v m s p 1 b 2$ and $63^{\circ} \mathrm{C}$ for $1 \mathrm{~min}$ for $P v m$ splb10, and $72^{\circ} \mathrm{C}$ for thirty seconds; followed by a final extension step at $72^{\circ} \mathrm{C}$ for $5 \mathrm{~min}$ and $4^{\circ} \mathrm{C}$ indefinitely. The following mixture was subjected to nested PCR in a 20$\mu \mathrm{L}$ volume: $1 \mu \mathrm{L}$ of product from the first PCR reaction (diluted 1:500 in $\mathrm{H}_{2} \mathrm{O}$ for Pvmsplb2 and 1:50 in $\mathrm{H}_{2} \mathrm{O}$ for Pvmsp1b10), $0.5 \mu \mathrm{M}$ each primer (Integrated DNA Technologies, San Diego, CA, USA), 0.125 mM dNTP mix, 3 $\mathrm{mM} \mathrm{MgCl}, 1 \mathrm{U}$ recombinant Taq polymerase (Invitrogen), and $2 \mu \mathrm{L} 10 \times$ Taq polymerase buffer (Invitrogen, Carlsbad, CA, USA). The cycling parameters included the following: 1 cycle at $94^{\circ} \mathrm{C}$ for $4 \mathrm{~min} ; 25$ cycles consisting of $94^{\circ} \mathrm{C}$ for $40 \mathrm{sec}, 63^{\circ} \mathrm{C}$ for $1 \mathrm{~min}$ for $P v m s p l b 2$ and $60^{\circ} \mathrm{C}$ for $1 \mathrm{~min}$ for Pvmsplb10, and $72^{\circ} \mathrm{C}$ for $40 \mathrm{sec}$; and a final cycle of $10 \mathrm{~min}$ at $72^{\circ} \mathrm{C}$.

The MSs ( $P v M S 1, P v M S 5$, PvMS6, and PvMS7) were amplified in a $20-\mu \mathrm{L}$ volume of $100-200 \mathrm{ng}$ DNA, $1 \mu \mathrm{M}$ each primer (Table I), $0.125 \mathrm{mM}$ dNTP mix, $1.5 \mathrm{mM}$ $\mathrm{MgCl}_{2} 1 \mathrm{U}$ Taq DNA polymerase (Invitrogen, Carlsbad,

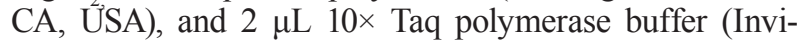
trogen, Carlsbad, CA, USA). The amplifications were performed in a Veriti thermocycler (Applied Biosystems,
Carlsbad, CA, USA) with one cycle of $94^{\circ} \mathrm{C}$ for $2 \mathrm{~min} ; 35$ cycles at $94^{\circ} \mathrm{C}$ for $30 \mathrm{sec}$, and then $53.4^{\circ} \mathrm{C}$ for $\mathrm{MS} 1,56^{\circ} \mathrm{C}$ for MS5 and MS7, and $58.6^{\circ} \mathrm{C}$ for MS6, all for $20 \mathrm{sec}$; and $72^{\circ} \mathrm{C}$ for $30 \mathrm{sec}$, ending in an extension step at $72^{\circ} \mathrm{C}$ for $2 \mathrm{~min}$.

For capillary electrophoresis, $2 \mu \mathrm{L}$ of a PCR product was mixed with $0.25 \mu \mathrm{L}$ of the standard size ET550-Rox genotyping size standard (GE Healthcare) and $7.75 \mu \mathrm{L}$ of $0.1 \%$ formamide HI-DITM. After capillary electrophoresis, alleles were visualised and scored using an automated DNA sequencer (ABI 3730xl DNA Analyzer, Applied Biosystems, California, USA). Their lengths and relative abundance (peak heights in electropherograms) were determined using GeneMapper Software version 4.1 (Applied Biosystems, California, USA). For the electropherogram analysis, the minimum peak height was set to 150 arbitrary fluorescence units (rFU). Additionally, a cut-off value for minor peak detection of one-third the height of the predominant peak was used to exclude artefact peaks.

\section{RESULTS AND DISCUSSION}

Two aliquots of a stool sample from an uninfected captive southern brown howler monkey were mixed with $100 \mu \mathrm{L}$ of blood from cultured $P$. falciparum strain 3D7 (13\% parasitaemia) or W2 (10\% parasitaemia). Another two aliquots were used as a negative control without the addition of Plasmodium. These four aliquots were used for genomic DNA extractions, and DNA of the 18SSU rRNA gene was amplified with primers specific for $P$. falciparum (Fig. 1). A fragment of 205 bp was successfully amplified from DNA extracted from the artificial mixture of monkey faeces with cultured $P$. falciparum and from a positive control of $P$. falciparum DNA directly extracted from culture.

In order to determine the detection limit of this assay, DNA from the artificial mixture of simian stool with cultured $P$. falciparum 3D7 was used in different concentrations. The DNA extracted from the artificial mixture of monkey stool (uninfected) and P. falciparum culture $\left(6.5 \times 10^{5}\right.$ parasites $\left./ \mu \mathrm{L}\right)$ and serial 10 -fold dilutions from $1: 100$ to $1: 1,000,000$ (equivalent amounts of parasites shown in Fig. 2) were used to detect Plasmodium infection by nested PCR (Fig. 2). The detection limit of this

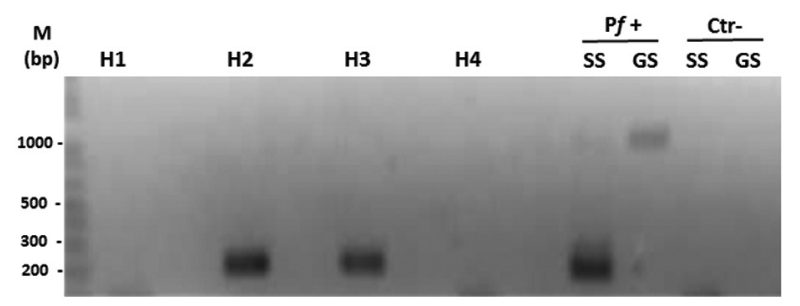

Fig. 1: nested polymerase chain reaction used to amplify the $18 \mathrm{SSU}$ rRNA fragment of Plasmodium falciparum in an artificial mixture of the parasite with uninfected faeces from a New World primate. Results were visualized on a $2 \%$ agarose gel stained with ethidium bromide. M: molecular weight marker (1-kb DNA ladder); H1 and H4: faecal samples without the parasite included; $\mathrm{H} 2$ and $\mathrm{H} 3$ : faecal samples with $P$. falciparum strains 3D7 and W2, respectively; Pf+: positive control for P. falciparum (cultured) using genus-specific primers (GS, 1,000 bp) and species-specific (SS, 240 bp) primers; Ctr-: negative control (without DNA). 


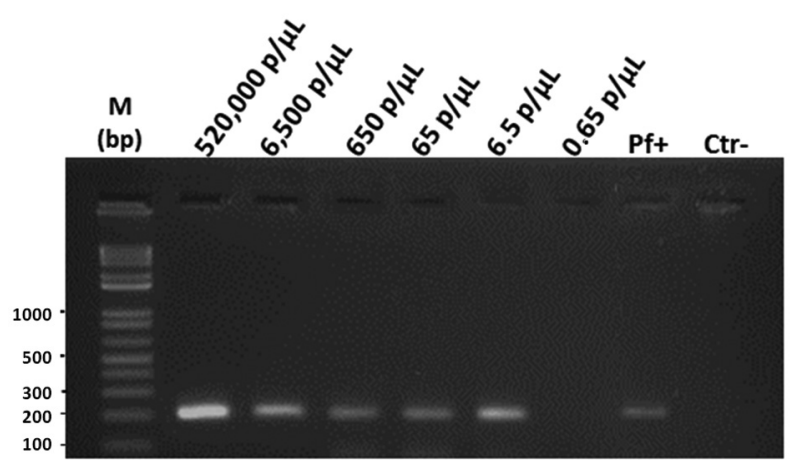

Fig. 2: detection limit of the parasite by polymerase chain reaction (PCR) in an artificial mixture of uninfected faeces from a New World primate with Plasmodium falciparum from in vitro culture. Molecular diagnosis of Plasmodium infection by nested PCR using primers for P. falciparum (205 bp). Results shown in a $2 \%$ agarose gel stained with ethidium bromide. M: molecular weight marker (1-kb DNA ladder); $\mathrm{Pf}+$ : positive control for $P$. falciparum, Ctr-: negative control (without DNA).

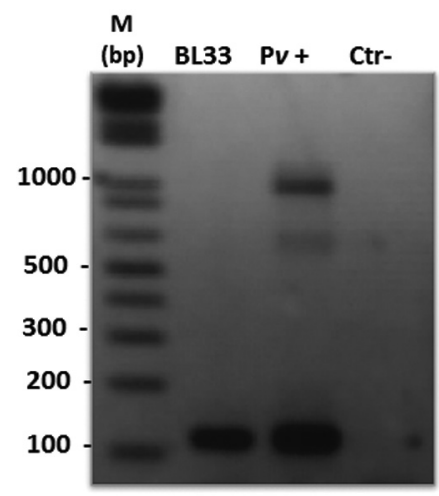

Fig. 3: natural Plasmodium vivax/Plasmodium simium infection detected in DNA extracted from the faeces of a captive Alouatta clamitans (BL33). Molecular diagnosis of Plasmodium infection was accomplished by nested polymerase chain reaction (18SSU rRNA) using specific primers for $P$. vivax. Results shown in a $2 \%$ agarose gel stained with ethidium bromide. $\mathrm{Pv}+$ : positive control (DNA from a $P$. vivax-infected patient) and Ctr-: negative control (without DNA); M: molecular weight marker (1-kb DNA ladder).

protocol was 6.5 parasites/ $\mu \mathrm{L}$ (dilution 1:100,000). Only the last DNA dilution, corresponding to 0.65 parasites/ $\mu \mathrm{L}$, was negative by the PCR assay.

Faecal samples from 23 brown howler monkeys, $A$. clamitans, from the Centre for Biological Research of Indaial (Santa Catarina, Brazil) were used for DNA extraction. The mammalian cytochrome $b$ gene was amplified to assess the quality of DNA in all samples (data not shown). Molecular diagnosis of Plasmodium infection was accomplished by nested PCR (18SSU rRNA) from the DNA extracted from faeces. One natural $P$. simium/P. vivax (BL33) infection was detected (Fig. 3). Negative controls did not show any amplified fragments, whereas positive controls showed fragments of the expected sizes (Fig. 3).
Surveys to determine the prevalence of Plasmodium parasites in monkeys are limited, primarily because of the difficulties involved in catching and handling animals in the field and the high cost of capture. Moreover, because of low parasitaemias and the chronicity of infection associated with several neotropical Plasmodium species, malaria is notoriously difficult to detect in monkeys by microscopy (Coatney 1971). PCR methods are considered more sensitive and specific; consequently, large-scale surveys to assess the prevalence and distribution of Plasmodium infections in NHPs that are based on PCR are required. Validation of a biological sampling technique that allows genomic DNA extraction without the necessity of monkey capture would be useful for epidemiological surveys of simian malaria in New World monkeys. Here, we report the first study using faecal samples of New World monkeys to detect neotropical Plasmodium species. In addition, the present study is the first to detect a natural infection with $P$. simium using DNA extracted from the faeces of a captive $A$. clamitans in southern Brazil.

Faeces are one of the most difficult biological samples to use for diagnosis by PCR because of the presence of various bacteria and products of feeding such as complex vegetal polysaccharides, which are potential inhibitors of the amplification (Monteiro et al. 1997). These challenges necessitate the use of a robust extraction and amplification methods. PCR inhibitors were removed during the extraction with InhibitEX resin and an optimised buffer in the silica membrane-based purification kit (QIAamp DNA Stool Mini Kit, Qiagen) (Fitzpatrick et al. 2010). We also tested the QIAamp Fast DNA Stool Mini Kit (Qiagen), because InhibitEX was easier to add as a buffer than as a tablet. However, no amplification was observed using this DNA isolation kit (data not shown).

In order to ensure DNA stability, monkey faeces were maintained in RNA Later at room temperature (20$24^{\circ} \mathrm{C}$ ) and frozen as soon as possible. Moreover, to overcome the effects of inhibitors that were not eliminated during the extraction step, we also used BSA as an additive during amplification.

Mharakurwa and colleagues (Mharakurwa et al. 2006) showed that shorter PCR amplicons could be amplified effectively from parasite DNA in human urine and saliva, despite the fact that DNA may be highly fragmented by the time it reaches these fluids. To optimise the detection of parasite DNA at low concentrations in faeces, it is necessary to use a multicopy target gene and consider the PCR amplicon size (Siregar et al. 2015). In this study, the MS and polymorphic blocks of the MSP1 gene, all of them resulting in short amplicons, were used for parasite genotyping. As measures to avoid contamination were undertaken and the PCR reactions were very well controlled (see Methods), the results presented here are not believed to be a result of cross-contamination in the laboratory.

Recently, the detection of DNA in faeces of monkeys by PCR was used to indicate the presence of parasites in the red blood cells of a host, rather than the presence of pre-erythrocytic parasites not established in the host (Abkallo et al. 2014). Here, the amplification of different genomic targets contradicts this; however, this possibility could not be excluded. 
To confirm natural Plasmodium infection, parasites in stool sample BL33 were genotyped using four MS loci and two polymorphic regions of MSP1 (Table II). The sizes of fragments obtained were compared to those of other monkeys genotyped in the laboratory and to human samples infected with P. vivax (Rezende et al. 2010). Based on results from MS1, MS5 and MS6, alleles previously identified in humans infected with $P$. vivax were also found in this study (Rezende et al. 2010, de Araújo et al. 2012). Furthermore, MS7 and the polymorphic regions of MSP1 in P. vivax (blocks 2 and 10) were found in both humans and monkeys infected with $P$. simium in a study conducted in other areas of the Atlantic Forest (unpublished data), suggesting that similar parasites are circulating among humans from endemic areas and monkeys from the Atlantic Forest. However, additional samples and molecular markers are needed to confirm this hypothesis. Results of the present study indicate that it is possible to detect Plasmodium in the faeces of New World monkeys and to use the data to monitor the genetic variation and dynamics of infection with the parasite.

According to the National Malaria Control Program (PNCM), Secretary for Health Surveillance (SVS), Ministry of Health, from January 2006 to December 2013, 8,410 cases of malaria were reported in the extra-Amazon Region, and 1,068 of these cases were autochthonous. More specifically, in 2013, of the 827 extra-Amazonian cases, $10.6 \%$ (88 cases) was acquired from autochthonous transmission (de Pina-Costa et al. 2014). In south and southeastern Brazil, human malaria transmission has been virtually eliminated or, for the past four decades, has only been reported during scattered outbreaks that began with imported cases (de Pina-Costa et al. 2014). However, a few autochthonous human malaria cases have been detected in the Atlantic Forest region, particularly in the mountain valleys in Southeast Brazil (Miguel et al. 2014). In such an environment, malaria transmission is supported by the bromeliad mosquito Anopheles (Kerteszia) cruzii, which has been implicated as the natural vector for both human and simian malaria in South and Southeast Brazil (Deane 1992). Therefore, in the 1990s, Deane and other authors more recently have suggested that human malaria in the Atlantic Forest could be a zoonosis with non-human primates NHPs as the reservoirs (Deane 1992, Duarte et al. 2008, de Pina-Costa et al. 2014). This study identified a natural $P$. simium infection by DNA extraction from the stool of a captive New World monkey. Taking into account that faeces collected from captive monkeys were probably relatively fresh, this protocol for field-collected samples still needs to be validated under more adverse environmental conditions. However, DNA has been successfully obtained from monkey's faeces in the field in Africa (Liu et al. 2010). Once autochthonous human cases of malaria are reported, the presence of wild reservoirs may have important implications for public health because of the close contact between humans and monkeys in some parts of the Atlantic Forest (de Pina-Costa et al. 2014).

Cases of simian malaria caused by neotropical Plasmodium species are neglected. The question of whether these NHPs are reservoirs for human malaria might be-
TABLE II

Genotyping of Plasmodium simium using molecular markers

\begin{tabular}{lc}
\hline Molecular Marker & Fragment size $(\mathrm{pb})$ \\
\hline MS1 & $224 *$ \\
MS5 & $191 * * *$ \\
MS6 & $209 * * *$ \\
MS7 & $324 * *$ \\
MSP1 (BLOCK 2) & $397 * * *$ \\
MSP1 (BLOCK 10) & $374 * *$
\end{tabular}

*: fragment size previously obtained from human samples; **: fragment size previously obtained from monkey samples; ***: fragment size previously obtained from monkey and human samples.

come important, especially if the disease is eradicated or eliminated in human populations. Epidemiological surveys of Plasmodium infections in wild New World monkeys are needed to assess the risk of exposure to zoonotic malaria, as recently described for $P$. knowlesi. Validation of a genomic DNA extraction method based on simple, less invasive and inexpensive sample collections can contribute to a better understanding of simian malaria. Faecal samples, therefore, offer an attractive alternative specimen for the detection of primate malaria. This is the first study to detect neotropical Plasmodium species from the faeces of New World monkeys. The present study identified a natural $P$. simium infection based on DNA extracted from the faeces of a captive $A$. clamitans (BL33) in southern Brazil.

\section{ACKNOWLEDGEMENTS}

To the Program for Technological Development of Health Products (PDTIS) sequencing facilities of Fiocruz and the team of the Center for Biological Research of Indaial (CEPESBI).

\section{REFERENCES}

Abkallo HM, Liu W, Hokama S, Ferreira PE, Nakazawa S, Maeno $\mathrm{Y}$, et al. DNA from pre-erythrocytic stage malaria parasites is detectable by PCR in the feces and blood of hosts. Int J Parasitol. 2014; 44(7): 467-73.

Alvarenga DA, de Pina-Costa A, de Sousa TN, Pissinatti A, Zalis MG, Suaréz-Mutis MC, et al. Simian malaria in the Brazilian Atlantic forest: first description of natural infection of capuchin monkeys (Cebinae subfamily) by Plasmodium simium. Malar J. 2015; 14: 81.

Araújo MS, Messias MR, Figueiró MR, Gil LH, Probst CM, Vidal NM, et al. Natural Plasmodium infection in monkeys in the state of Rondônia (Brazilian Western Amazon). Malar J. 2013; 12: 180.

Arruda ME, Nardini EH, Nussenzweig RS, Cochrane AH. Sero-epidemiological studies of malaria in indian tribes and monkeys of the Amazon basin of Brazil. Am J Trop Med Hyg. 1989; 41(4): 379-85.

Cerutti-Junior C, Boulos M, Coutinho AF, Hatab MCLD, Falqueto A, Rezende $\mathrm{H}$, et al. Epidemiologic aspects of the malaria transmission cycle in an area of very low incidence in Brazil. Malar J. 2007; 6: 33.

Coatney GR. The simian malarias: zoonoses, anthroponoses, or both? Am J Trop Med Hyg. 1971; 20(6): 795-803. 
de Araújo FC, de Rezende AM, Fontes CJ, Carvalho LH, de Brito CF. Multiple-clone activation of hypnozoites is the leading cause of relapse in Plasmodium vivax infection. PLoS ONE. 2012; 7(11): e49871.

de Pina-Costa A, Brasil P, Di Santi SM, de Araujo MP, Suárez-Mutis MC, Santelli ACFS, et al. Malaria in Brazil: what happens outside the Amazonian endemic region. Mem Inst Oswaldo Cruz. 2014; 109(5): 618-33.

Deane LM, Deane MP, Ferreira Neto J. Studies on transmission of simian malaria and on the natural infection of man with Plasmodium simium in Brazil. Bull World Health Organ. 1966; 35(5): 805-8.

Deane LM. Simian malaria in Brazil. Mem Inst Oswaldo Cruz. 1992; 87(Suppl. III): 1-20.

Duarte AM, Malafronte RS, Cerutti C, Curado I, de Paiva BR, Maeda AY, et al. Natural Plasmodium infections in Brazilian wild monkeys: reservoirs for human infections? Acta Trop. 2008; 107(2): 179-85.

Fandeur T, Volney B, Peneau C, de Thoisy B. Monkeys of the rainforest in French Guiana are natural reservoirs for P. brasilianum/P. malariae malaria. Parasitology. 2000; 120(Pt 1): 11-21.

Fitzpatrick KA, Kersh GJ, Massung RF. Practical method for extraction of PCR-quality DNA from environmental soil samples. Appl Environ Microbiol. 2010; 76(13): 4571-3.

Galinski MR, Barnwell JW. Monkey malaria kills four humans. Trends Parasitol. 2009; 25(5): 200-4.

Jirků M, Pomajbíková K, Petrželková KJ, Hůzová Z, Modrý D, Lukeš J. Detection of Plasmodium spp. in human feces. Emerg Infect Dis. 2012; 18(4): 634-6.

Kocher TD, Thomas WK, Meyer A, Edwards SV, Pääbo S, Villablanca FX, et al. Dynamics of mitochondrial DNA evolution in animals: amplification and sequencing with conserved primers. Proc Natl Acad Sci USA. 1989; 86(16): 6196-200.

Leclerc M, Hugot J, Durand P, Renaud F. Evolutionary relationships between 15 Plasmodium species from new and old world primates (including humans): an $18 \mathrm{~S}$ rDNA cladistic analysis. Parasitology. 2004; 129(Pt 6): 677-84.

Liu W, Li Y, Learn GH, Rudicell RS, Robertson JD, Keele BF, et al. Origin of the human malaria parasite Plasmodium falciparum in gorillas. Nature. 2010; 467(7314): 420-5.
Liu W, Li Y, Shaw KS, Learn GH, Plenderleith LJ, Malenke JA, et al. African origin of the malaria parasite Plasmodium vivax. Nat Commun. 2014; 5: 3346.

Lourenço-de-Oliveira R, Deane LM. Simian malaria at two sites in the Brazilian Amazon. I - The infection rates of Plasmodium brasilianum in non-human primates. Mem Inst Oswaldo Cruz. 1995; 90(3): 331-9.

Mharakurwa S, Simoloka C, Thuma PE, Shiff CJ, Sullivan DJ. PCR detection of Plasmodium falciparum in human urine and saliva samples. Malar J. 2006; 5: 103.

Miguel RB, Peiter PC, de Albuquerque H, Coura JR, Moza PG, Costa AP, et al. Malaria in the state of Rio de Janeiro, Brazil, an Atlantic Forest area: an assessment using the health surveillance service. Mem Inst Oswaldo Cruz. 2014; 109(5): 634-40.

Monteiro L, Bonnemaison D, Vekris A, Petry KG, Bonnet J, Vidal R, et al. Complex polysaccharides as PCR inhibitors in feces: Helicobacter pylori model. J Clin Microbiol. 1997; 35(4): 995-8.

Nwakanma DC, Gomez-Escobar N, Walther M, Crozier S, Dubovsky F, Malkin E, et al. Quantitative detection of Plasmodium falciparum DNA in saliva, blood, and urine. J Infect Dis. 2009; 199(11): 1567-74.

Rezende AM, Tarazona-Santos E, Fontes CJ, Souza JM, Couto AD, Carvalho LH, et al. Microsatellite loci: determining the genetic variability of Plasmodium vivax. Trop Med Int Health. 2010; 15(6): 718-26.

Singh B, Sung LK, Matusop A, Radhakrishnan A, Shamsul SS, Cox-Singh $\mathrm{J}$, et al. A large focus of naturally acquired Plasmodium knowlesi infections in human beings. Lancet. 2004; 363(9414): 1017-24.

Siregar JE, Faust CL, Murdiyarso LS, Rosmanah L, Saepuloh U, Dobson AP, et al. Non-invasive surveillance for Plasmodium in reservoir macaque species. Malar J. 2015; 14: 404.

Snounou G, Viriyakosol S, Jarra W, Thaithong S, Brown KN. Identification of the four human malaria parasite species in field samples by the polymerase chain reaction and detection of a high prevalence of mixed infections. Mol Biochem Parasitol. 1993; 58(2): 283-92.

White NJ. Plasmodium knowlesi: the fifth human malaria parasite. Clin Infect Dis. 2008; 46(2): 172-3.

Yusof R, Lau YL, Mahmud R, Fong MY, Jelip J, Ngian HU, et al. High proportion of knowlesi malaria in recent malaria cases in Malaysia. Malar J. 2014; 13: 168. 